\title{
Amino acid content of selected plant, algae and insect species: a search for alternative protein sources for use in pet foods*
}

\author{
Sarah McCusker ${ }^{1}$, Preston R. Buff ${ }^{2}$, Zengshou $\mathrm{Yu}^{1}$ and Andrea J. Fascetti ${ }^{1 \dagger}$ \\ ${ }^{1}$ Department of Molecular Biosciences, School of Veterinary Medicine, University of California, Davis, CA, 95616, USA \\ ${ }^{2}$ The Nutro Company, Franklin, TN 37067, USA
}

(Received 11 November 2013 - Final revision received 19 February 2014 - Accepted 27 February 2014)

Journal of Nutritional Science (2014), vol. 3, e39, page 1 of 5

doi:10.1017/jns.2014.33

Abstract

In response to global economic duress and heightened consumer awareness of nutrition and health, sustainable and natural ingredients are in demand. Identification of alternative sources of nitrogen and amino acids, including taurine, may help meet dietary requirements while fostering sustainability and natural feeding approaches. Twenty plants, eighteen marine algae and five insect species were analysed. All samples were freeze-dried, hydrolysed and filtered prior to amino acid analysis. Samples for amino acids were analysed in duplicate and averaged. Nitrogen was analysed and crude protein (CP) determined by calculation. With the exception of taurine concentration in soldier fly larvae, all insects exceeded both the National Research Council's canine and feline minimal requirements (MR) for growth of all essential amino acids (EAA) and CP. Although some plants and marine algal species exceeded the canine and feline MR for growth for EAA and CP, only very low concentrations of taurine were found in plants. Taurine concentration in insects was variable but high, with the greatest concentration found in ants $(6.42 \mathrm{mg} / \mathrm{g} \mathrm{DM})$ and adult flesh flies $(3.33 \mathrm{mg} / \mathrm{g}$ DM). Taurine was also high in some macroalgae, especially the red algal species: Mazaella spp. (4.11 mg/g DM), Porphyra spp. (1.22 mg/g DM) and Chondracanthus spp. $(6.28 \mathrm{mg} / \mathrm{g} \mathrm{DM})$. Preliminary results suggest that insects and some marine algal species may be practical alternatives to traditional protein and supplemental taurine sources in pet foods. Safety, bioavailability, palatability and source variability of alternative items as food ingredients should be investigated prior to incorporation into canine and feline diets.

Key words: Amino acids: Protein: Taurine: Canine nutrition: Feline nutrition

Pet ownership brings many physiological and psychological benefits, and approximately one-third of households in the USA own a dog or cat ${ }^{(1)}$. That translates into approximately 70 million dogs and $74 \cdot 1$ million cats ${ }^{(2)}$. However, the sustainability of owning a pet has been a topic of public discussion recently, with a particular focus on nutrition.

Protein is the most expensive macronutrient in ecologic and economic terms and therefore the one requiring the most attention with respect to sustainability ${ }^{(3)}$. Protein is required for two reasons; to provide essential amino acids (EAA) that cannot be synthesised by dogs and cats from their diet, and to provide dispensable amino acids that in turn provide nitrogen and carbon for the synthesis of other dispensable amino acids, gluconeogenesis and energy. Dogs and cats require nitrogen and ten $\mathrm{EAA}$, arginine, histidine, isoleucine, leucine, lysine, methionine, phenylalanine, threonine, tryptophan and valine. In addition, cats have a dietary requirement for taurine ${ }^{(4)}$.

Taurine is a sulphur-containing amino acid found in highest concentration within cardiac and skeletal muscle ${ }^{(5,6)}$. It has been documented to a lesser extent in algae, bacteria, fungi and some higher plants ${ }^{(7-10)}$. This free amino acid has a role in a variety of physiologic processes in animals, including conjugation of bile acids, maintaining normal retinal and

Abbreviations: CP, crude protein; EAA, essential amino acids; MR, minimal requirements.

†Corresponding author: A. J. Fascetti, fax +1 530752 4698, email ajfascetti@ucdavis.edu

* This article was published as part of the WALTHAM International Nutritional Sciences Symposium Proceedings 2013. 
myocardial function, osmoregulation and modulation of calcium flux within cells as well as reproduction and immune response ${ }^{(5,6)}$. Low blood or plasma taurine concentrations in strict carnivores have been directly linked to retinal degeneration and cardiomyopathy ${ }^{(11-13)}$, making taurine an EAA for cats $^{(4)}$. Therefore, the minimum dietary inclusion concentrations of taurine in cat foods have been established by the Association of American Feed Control Officials (AAFCO) at $0 \cdot 1-0 \cdot 20 \%(\mathrm{DM})^{(14)}$ and The European Pet Food Industry Federation (FEDIAF) at $0.2-0.25 \%(\mathrm{DM})^{(15)}$. With the exception of felids and other strict carnivores, taurine is not recognised as an essential nutrient in most species as it can be synthesised from adequate dietary methionine and cystine ${ }^{(5,13)}$. Because it is not considered nutritionally essential beyond the cat, inclusion levels in canine foods have not been regulated. However, recent documentation of links between low blood and plasma taurine concentrations and the onset of dilated cardiomyopathy in dogs have been reported in the scientific literature ${ }^{(16-18)}$. These findings have motivated pet food companies to supplement taurine at discretionary levels in some commercial foods, leading to a demand for not only high-quality protein ingredients, but also additional sources of taurine.

The quality of ingredients and the inclusion of animal-based protein sources in pet foods are very important factors pet owners consider when selecting a diet ${ }^{(19,20)}$. This bias may put human subjects in direct competition with pets for many protein resources in the future. However, dogs and cats as well as human subjects need nutrients and not ingredients. Their nutrient requirements can be met through a variety, or often a combination, of animal or plant-derived protein sources.

In response to potential global economic duress and heightened consumer awareness regarding issues of nutrition and health, sustainable, and natural or organic ingredients are more in demand. Identification of additional sources of nitrogen and amino acids, including taurine, will help meet the dietary requirements of cats and dogs, lessening the competition for food resources. Therefore, our objectives were to report nitrogen and amino acid profiles of various plants, algal and insect substrates to begin to identify potential new ingredients for use in canine and feline diets.

\section{Experimental methods}

\section{Acquisition and preparation of plants, algae and insects}

It was our goal to select readily accessible, prolific plant species that can be cultivated and harvested at a rate conducive to production demands. We obtained produce items from local vendors. These items were rinsed then homogenised with a food processor. Marine algae samples were obtained from the UC Davis Bodega Bay Marine Laboratory (BML), Bodega Bay, CA, USA in February 2012. Holdfasts were removed and algae specimens were rinsed with deionised water and patted dry with paper towels. Cockroaches (Periplaneta americana), duckweed (Lemna spp.), blow fly larvae and adults (Sarcophaga bullata), and ants (Pogonomyrmex occidentalis) were purchased from Carolina Biological Supply Company (Carolina.com). Soldier fly larvae (Hermetia illucens) were purchased from Josh's Frogs (joshsfrogs.com). Live insects were fasted to empty GI tract of ingesta. All samples were stored frozen at $-80^{\circ} \mathrm{C}$ prior to lyophilising using a standard vacuum coil freeze dryer (VirTis Freeze Mobile 25EL, SP Scientific).

\section{Amino acid and nitrogen analysis}

After freeze-drying, all samples were ground to pass through a $2 \mathrm{~mm}$ screen (80 mesh). Roughly $10 \mathrm{mg}$ of this ground sample was hydrolysed in a vacuumed-sealed glass ampule with $2 \mathrm{ml}$ $6 \mathrm{M} \mathrm{HCl}$ at $115^{\circ} \mathrm{C}$ for $24 \mathrm{~h}$. The hydrolysate was then dried with nitrogen gas and the resulting residue reconditioned with $\mathrm{LiOH}$ loading buffer. We filtered this solution using a $0.45 \mu \mathrm{M}$ polytetrafluorethylene syringe filter, and from the filtrate, amino acid composition was determined using a norleucine standard and an automated amino acid analyser (HPLC, Biochrom 30, Biochrom Ltd) at the Amino Acid Laboratory at the University of California, Davis, CA, USA using previously published techniques ${ }^{(9)}$. Cystine and methionine were determined using the performic acid oxidation with acid hydrolysis, hydrobromic acid method ${ }^{(21)}$, and tryptophan using a previously described method ${ }^{(22)}$. DM of substrates was determined by placing a known amount of sample in a $100^{\circ} \mathrm{C}$ oven for $24 \mathrm{~h}$, or until a stable weight was achieved. Samples for amino acid determination were analysed in duplicate for each item, averaged and reported on a DM basis. Owing to sample amount remaining, Trp was only analysed once. Nitrogen was analysed in the UC Davis Analytical Laboratory by combustion and crude protein (CP) was determined by calculation and reported on a DM basis ${ }^{(23,24)}$.

\section{Results}

All insects exceeded both the National Research Council's canine and feline minimal requirements (MR) for growth of all EAA and CP (Tables 1 and 2). Some, but not all plants and marine algal species exceeded the canine and feline National Research Council's MR for growth for EAA and CP. No appreciable amount of taurine was found in any plants. Taurine concentration in insects was variable, but high, with the greatest concentration found in ants $(6.42 \mathrm{mg} / \mathrm{g}$ DM) and adult flesh flies $(3.33 \mathrm{mg} / \mathrm{g}$ DM). One species of green algae and many members of the group Phaeophyta did not yield high amounts of taurine. However, taurine was high in some red algal species including: Mazaella spp. (4.11 mg/g DM), Porphyra spp. (1.22 mg/g DM) and Chondracanthus spp. (6.28 mg/g DM). Dispensable amino acid concentrations for all plants, algae and insects analysed are reported in Tables 3 and 4 as supplemental material.

\section{Discussion}

In order to address the growing importance of protein sources in animal nutrition, we sought to identify alternative, sustainable sources of nitrogen and EAA. While the use of plantderived proteins is common practice in commercial canine 
Table 1. Crude protein and essential amino acids of produce items

Amino acid (mg/g DM)*

\begin{tabular}{|c|c|c|c|c|c|c|c|c|c|c|c|c|}
\hline & $\mathrm{CP}(\% \mathrm{DM}) \dagger$ & Arg & His & Ile & Leu & Lys & Met & Phe & Tau & Thr & Trp & Val \\
\hline Land cress (Barbarea verna) & 45.5 & $17 \cdot 72$ & 6.39 & $11 \cdot 20$ & 20.51 & $18 \cdot 74$ & 1.40 & $15 \cdot 18$ & 0.04 & $12 \cdot 83$ & 4.63 & $15 \cdot 74$ \\
\hline Purple kale (Brassica oleracea) & $27 \cdot 6$ & 5.5 & 3.62 & 4.78 & $7 \cdot 32$ & $8 \cdot 33$ & $2 \cdot 34$ & 4.33 & 0.02 & $6 \cdot 16$ & 1.60 & $8 \cdot 25$ \\
\hline Dandelion (Taraxacum officinale) & $23 \cdot 8$ & 13.51 & 4.96 & $10 \cdot 45$ & $19 \cdot 34$ & $15 \cdot 40$ & 4.03 & $12 \cdot 84$ & 0.00 & 11.58 & 3.64 & 13.57 \\
\hline Red chard (Beta vulgaris v. cicla) & $26 \cdot 4$ & 11.67 & 5.03 & 8.77 & $16 \cdot 73$ & $14 \cdot 33$ & $3 \cdot 21$ & 11.07 & 0.00 & $9 \cdot 37$ & $3 \cdot 17$ & $12 \cdot 07$ \\
\hline Okra (Abelmoschus esculentus) & $15 \cdot 3$ & 8.69 & 2.60 & 4.57 & 8.33 & $9 \cdot 00$ & 2.01 & 4.88 & 0.02 & $5 \cdot 65$ & 1.60 & $6 \cdot 29$ \\
\hline Acai berry puree (Euterpeoleracea) & $9 \cdot 2$ & 5.08 & 2.06 & 3.96 & $7 \cdot 60$ & $6 \cdot 45$ & $1 \cdot 23$ & 4.89 & 0.00 & 4.89 & 1.54 & $5 \cdot 27$ \\
\hline Prickly pear (Opuntia ficus-indica (fruits)) & 3.7 & 1.59 & $1 \cdot 17$ & 1.08 & $2 \cdot 37$ & 2.07 & 0.49 & 1.40 & 0.00 & $1 \cdot 18$ & 0.31 & 1.46 \\
\hline Pomegranate (Punica granatum) & $7 \cdot 6$ & 6.33 & 1.53 & 1.78 & 3.62 & $1 \cdot 84$ & 0.79 & $2 \cdot 12$ & 0.00 & 1.87 & 0.95 & $2 \cdot 12$ \\
\hline Blueberry (Vaccinium cyanococcus) & $4 \cdot 7$ & $4 \cdot 12$ & 0.69 & 1.05 & $2 \cdot 14$ & 1.96 & 0.44 & $1 \cdot 25$ & 0.00 & $1 \cdot 22$ & 0.56 & 1.40 \\
\hline White sapote (Casimiroa edulis) & 3.6 & 1.56 & 0.77 & $1 \cdot 18$ & 2.80 & $2 \cdot 41$ & 0.45 & 1.46 & 0.00 & 1.50 & 0.45 & 1.58 \\
\hline Plum (Prunus spp.) & 3.9 & 0.67 & 0.52 & $2 \cdot 16$ & 1.69 & 1.41 & 0.19 & 1.05 & 0.00 & 0.99 & 0.15 & $1 \cdot 24$ \\
\hline Beet greens (Beta vulgaris v. conditiva) & $25 \cdot 9$ & 8.63 & 4.43 & $6 \cdot 62$ & 11.90 & $10 \cdot 55$ & $2 \cdot 30$ & $7 \cdot 66$ & 0.02 & $6 \cdot 64$ & $2 \cdot 26$ & 8.93 \\
\hline Beetroot (Beta vulgaris v. conditiva) & $17 \cdot 7$ & $3 \cdot 32$ & $2 \cdot 30$ & $3 \cdot 22$ & 4.90 & 4.53 & 1.05 & 2.32 & 0.00 & 2.91 & 0.75 & 3.61 \\
\hline Cherimoya (Annona cherimola) & $6 \cdot 6$ & 2.58 & $1 \cdot 22$ & 2.04 & $4 \cdot 15$ & $3 \cdot 82$ & 0.82 & 2.62 & 0.00 & $2 \cdot 14$ & 0.55 & 2.64 \\
\hline Jalepeno pepper (Capsicum annum) & $14 \cdot 7$ & 6.59 & 2.72 & $5 \cdot 13$ & 8.93 & 9.90 & 2.08 & $6 \cdot 36$ & 0.01 & 5.97 & $1 \cdot 21$ & $6 \cdot 91$ \\
\hline Eggplant (Solanum melongena) & 14 & $7 \cdot 18$ & 2.92 & 4.63 & $7 \cdot 66$ & $8 \cdot 10$ & 1.55 & 4.69 & 0.00 & $4 \cdot 22$ & $1 \cdot 12$ & $6 \cdot 70$ \\
\hline Taro root (Colocasia esculenta) & $7 \cdot 3$ & $6 \cdot 10$ & 1.68 & 2.67 & $6 \cdot 82$ & 3.88 & 0.96 & $4 \cdot 32$ & 0.00 & $3 \cdot 16$ & 0.86 & $4 \cdot 13$ \\
\hline $\begin{array}{l}\text { Brewer's yeast (Saccharomyces } \\
\text { cerevisiae) }\end{array}$ & $55 \cdot 2$ & 25.53 & $11 \cdot 25$ & $24 \cdot 31$ & $37 \cdot 20$ & $44 \cdot 26$ & 8.06 & $22 \cdot 52$ & 0.00 & $25 \cdot 74$ & $6 \cdot 18$ & $30 \cdot 26$ \\
\hline Duckweed (Lemna spp.) & $24 \cdot 8$ & $11 \cdot 12$ & 3.43 & $6 \cdot 72$ & $15 \cdot 26$ & 11.54 & $3 \cdot 13$ & $9 \cdot 85$ & 0.00 & $8 \cdot 33$ & $3 \cdot 10$ & 9.05 \\
\hline Cactus fruit (Ferocactus spp.) & $10 \cdot 6$ & $14 \cdot 13$ & 2.77 & $3 \cdot 30$ & 6.51 & $3 \cdot 83$ & $3 \cdot 24$ & 4.5 & 0.00 & 3.4 & 1.41 & 3.96 \\
\hline NRC MR Canine for growth & $18 \cdot 0$ & $6 \cdot 3$ & $3 \cdot 1$ & $5 \cdot 2$ & $10 \cdot 3$ & $7 \cdot 0$ & 2.8 & $5 \cdot 2$ & NR‡ & 6.5 & $1 \cdot 8$ & $5 \cdot 4$ \\
\hline NRC MR Feline for growth & $18 \cdot 0$ & $7 \cdot 7$ & 2.6 & $4 \cdot 3$ & $10 \cdot 2$ & $6 \cdot 8$ & 3.5 & $4 \cdot 0$ & 0.32 & $5 \cdot 2$ & $1 \cdot 3$ & $5 \cdot 1$ \\
\hline
\end{tabular}

CP, Crude protein; NRC MR, National Research Council Minimal Requirement; NR, not required.

*Sample for each amino acid determination analysed in duplicate and reported as a mean value, with the exception of Trp in which only one sample was analysed due to sample size.

†Crude protein expressed on a \% (w/w) DM basis.

$\ddagger$ Taurine is not considered an essential amino acid in the dog.

and feline diets, the investigation of plants as a source of taurine has either been overlooked or very difficult as indicated by the lack of reports in the literature. Other alternative sources of nitrogen and EAA such as insects, fungi, and algae have also been little studied. Identification of non-animal tissue sources of nitrogen and EAA, including taurine, will expand the substrates available to animal food manufacturers, enhancing flexibility within diet formulation. The potential economic benefit of propagating such sources compared to animal pools is a likely avenue to decrease production costs while supporting sustainability.

With the exception of taurine concentration in soldier fly larvae, all insects analysed in the present study yielded CP, EAA and taurine concentrations in excess of the National Research Council's MR for dogs and cats. Taurine ranged from 0.19 $\mathrm{mg} / \mathrm{g}$ DM in soldier fly larvae to $6.42 \mathrm{mg} / \mathrm{g}$ DM in harvester ants. Similarly, Finke found insects to be a good source of nutrients, including taurine. Crickets (Acheta domestics) were highest among species analysed in that report, yielding $1.4 \mathrm{mg}$ taurine $/ \mathrm{g}$ for adults and $0.8 \mathrm{mg}$ taurine/g for nymphs on an as is basis ${ }^{(25)}$. Although insects provide adequate amounts of EAA, acceptability as a pet food ingredient may be variable in different cultures. Additionally, insects feed on a variety of substrates, including plants that are known to be toxic to companion animals. The authors concluded that the safety and palatability of insects as food for dogs and cats should be investigated prior to incorporation into commercial diets ${ }^{(25)}$.

Not all algal species analysed met or exceeded the National Research Council's MR for dogs and cats for CP or EAA.
For alternative taurine sources, the most promising substrates in the present study were species of red algae, including Chondracanthus spp., Mazaella spp, and Porphyras pp. all of which met or exceeded the AAFCO and FEDIAF feline requirementfortaurine $(0 \cdot 1 \% \mathrm{DM})$ in extruded diets and the first two also exceeding the AAFCO and FEDIAF feline requirement for canned foods $(0 \cdot 2,0.25 \% \mathrm{DM}$, respectively). Of particular interest is the Chondracanthus specimen, which yielded an average taurine concentration of $6.3 \mathrm{mg} / \mathrm{g}$ DM, similar to concentrations reported for various seafood items (i.e. fish or clams), and the Marzaella specimen, with similar taurine concentration to that of animal tissue ${ }^{(9)}$.Our findings are in agreement with another study that reported red algae contained higher concentrations of taurine $(0.13 \mathrm{~g} / \mathrm{kg}$ as is) compared to green $(0.002 \mathrm{~g} /$ $\mathrm{kg}$ as is) or brown $\left(0.01 \mathrm{~g} / \mathrm{kg}\right.$ as is) algae species ${ }^{(7)}$.

As with insects, further investigation is necessary before incorporating various species of algae into animal diets. Some species of brown algae have been shown to contain polysaccharides that have anti-pepsin activity in vitro, and could compromise overall protein digestibility of a diet ${ }^{(26)}$. It is possible that seaweed polysaccharides whose physiochemical properties have not been investigated also exhibit antinutritional characteristics, but more research is needed.

Similar to several previous investigations, standard grocery store items (fruits and vegetables) yielded no significant amounts of taurine. Contrary to other investigations that reported fruits from the Opuntia cultivars to contain taurine in the range of 0.07 to $0.57 \mathrm{~g} / \mathrm{kg}$ on an as is basis ${ }^{(8,10,27)}$, the cactus fruit analysed in our study did not yield any taurine. While not 
Table 2. Crude protein and essential amino acids of selected marine macroalgae and insects

\begin{tabular}{|c|c|c|c|c|c|c|c|c|c|c|c|c|}
\hline & \multirow{2}{*}{$\begin{array}{l}\text { CP }(\% \\
\text { DM)† }\end{array}$} & \multicolumn{11}{|c|}{ Amino acid (mg/g DM)* } \\
\hline & & Arg & His & Ile & Leu & Lys & Met & Phe & Tau & Thr & Trp & Val \\
\hline \multicolumn{13}{|l|}{ Chlorophyta (green algae) } \\
\hline $\begin{array}{l}\text { Ulva spp. } \\
\text { Phaeophyta (brown algae) }\end{array}$ & 28.5 & $16 \cdot 00$ & 4.52 & $9 \cdot 26$ & $16 \cdot 76$ & 11.61 & 4.47 & 11.67 & 0.01 & $14 \cdot 34$ & 4.55 & $16 \cdot 32$ \\
\hline Eisenia arborea & $26 \cdot 2$ & $17 \cdot 35$ & 9.94 & $8 \cdot 88$ & $14 \cdot 20$ & $18 \cdot 02$ & $4 \cdot 12$ & 9.66 & 0.07 & 11.92 & 1.76 & $12 \cdot 66$ \\
\hline Hedophyllum sessile & $15 \cdot 6$ & $6 \cdot 17$ & $2 \cdot 29$ & $5 \cdot 37$ & $10 \cdot 27$ & $9 \cdot 26$ & 2.60 & $7 \cdot 10$ & 0.02 & 8.77 & $1 \cdot 32$ & 8.09 \\
\hline Dictyoneurum californicum & $17 \cdot 2$ & $6 \cdot 35$ & 2.56 & $5 \cdot 66$ & $9 \cdot 30$ & $10 \cdot 11$ & 2.68 & 6.72 & 0.00 & 8.65 & 1.74 & $8 \cdot 19$ \\
\hline Macrocystis spp. & $17 \cdot 6$ & 4.04 & 1.35 & 3.29 & 5.69 & $4 \cdot 30$ & 2.00 & 3.79 & 0.10 & 3.63 & $2 \cdot 13$ & 4.46 \\
\hline Laminaria spp. & $14 \cdot 0$ & 5.42 & $2 \cdot 21$ & $4 \cdot 34$ & $8 \cdot 39$ & 9.97 & $2 \cdot 17$ & 5.48 & 0.02 & 7.01 & & $6 \cdot 68$ \\
\hline Fucus gardneri & 11.7 & $5 \cdot 30$ & 1.85 & 4.59 & $8 \cdot 11$ & $7 \cdot 25$ & $2 \cdot 36$ & $5 \cdot 17$ & 0.00 & $5 \cdot 22$ & 1.63 & $5 \cdot 70$ \\
\hline Egregria menziessii & 14.9 & 6.69 & $2 \cdot 33$ & $5 \cdot 89$ & $10 \cdot 06$ & 11.66 & $2 \cdot 60$ & 7.02 & 0.02 & 7.58 & 1.65 & $8 \cdot 52$ \\
\hline Pelvetropsis limitata & 11.4 & 4.29 & 1.61 & 3.76 & 6.67 & $6 \cdot 30$ & 1.93 & $4 \cdot 38$ & 0.01 & 4.56 & 1.42 & 4.91 \\
\hline Lessoniopsis littoralis & $14 \cdot 8$ & 5.04 & $1 \cdot 70$ & 4.82 & 8.66 & 12.08 & $2 \cdot 25$ & $5 \cdot 75$ & 0.02 & $8 \cdot 10$ & $1 \cdot 12$ & 8.48 \\
\hline Pterygophora californica & 11.4 & 3.40 & 1.63 & 3.23 & $5 \cdot 77$ & $7 \cdot 25$ & 1.58 & 3.79 & 0.00 & 4.84 & 1.04 & 5.00 \\
\hline \multicolumn{13}{|l|}{ Rhodophyta (red algae) } \\
\hline Mazzaella spp. & $17 \cdot 5$ & $11 \cdot 76$ & 2.45 & $6 \cdot 88$ & 11.68 & $10 \cdot 09$ & 3.44 & $7 \cdot 37$ & $4 \cdot 11$ & 6.93 & 1.39 & $8 \cdot 90$ \\
\hline Palmaria hecatensis & 23.6 & $12 \cdot 56$ & $3 \cdot 25$ & 8.55 & $15 \cdot 33$ & $15 \cdot 40$ & 4.91 & $10 \cdot 19$ & 0.60 & $10 \cdot 46$ & 2.91 & 12.08 \\
\hline Neorhodo melalarix & $21 \cdot 2$ & $9 \cdot 12$ & 3.05 & 6.96 & $11 \cdot 18$ & $16 \cdot 66$ & 3.73 & $9 \cdot 70$ & 0.10 & $8 \cdot 19$ & $1 \cdot 31$ & 8.79 \\
\hline Porphyra spp. & $8 \cdot 3$ & 6.93 & $1 \cdot 27$ & 3.61 & $6 \cdot 16$ & $5 \cdot 18$ & 1.66 & $4 \cdot 25$ & 1.22 & 3.69 & 0.54 & 4.79 \\
\hline Cryptopleura ruprechtiana & $27 \cdot 9$ & $16 \cdot 81$ & $7 \cdot 73$ & $8 \cdot 80$ & 14.50 & 23.00 & $4 \cdot 15$ & 11.92 & 0.01 & 13.04 & $2 \cdot 90$ & $13 \cdot 16$ \\
\hline Chondracanthus spp. & $14 \cdot 8$ & $10 \cdot 23$ & $2 \cdot 27$ & $6 \cdot 00$ & $10 \cdot 23$ & 8.48 & 2.92 & 7.02 & $6 \cdot 28$ & 6.74 & 1.46 & $8 \cdot 17$ \\
\hline $\begin{array}{l}\text { Prionotis spp. } \\
\text { Insects }\end{array}$ & $36 \cdot 9$ & $19 \cdot 39$ & $4 \cdot 10$ & $13 \cdot 84$ & $20 \cdot 84$ & 20.91 & $9 \cdot 34$ & $16 \cdot 66$ & 0.03 & $15 \cdot 02$ & $3 \cdot 39$ & $17 \cdot 25$ \\
\hline $\begin{array}{l}\text { American cockroach (Periplaneta } \\
\text { americana) }\end{array}$ & $95 \cdot 8$ & 33.71 & $15 \cdot 41$ & $18 \cdot 81$ & $35 \cdot 86$ & 34.91 & 8.90 & $19 \cdot 68$ & $1 \cdot 10$ & $21 \cdot 01$ & $4 \cdot 71$ & 30.99 \\
\hline $\begin{array}{l}\text { Flesh fly, larva (Sarcophaga (Neobelliaria) } \\
\text { bullata) }\end{array}$ & $65 \cdot 8$ & $35 \cdot 69$ & 23.47 & $27 \cdot 40$ & $44 \cdot 86$ & $56 \cdot 14$ & $15 \cdot 96$ & $40 \cdot 62$ & 0.92 & $27 \cdot 15$ & 8.93 & 35.46 \\
\hline $\begin{array}{l}\text { Western harvester ant } \\
\text { (Pogonomyrmexoccidentalis) }\end{array}$ & $66 \cdot 3$ & $25 \cdot 72$ & $15 \cdot 13$ & $30 \cdot 33$ & 46.92 & 28.42 & 8.03 & $16 \cdot 15$ & $6 \cdot 42$ & $24 \cdot 36$ & NA & 37.94 \\
\hline $\begin{array}{l}\text { Flesh fly, adult (Sarcophaga (Neobelliaria) } \\
\qquad \text { bullata) }\end{array}$ & $78 \cdot 6$ & $44 \cdot 27$ & $24 \cdot 88$ & 32.05 & $51 \cdot 80$ & $61 \cdot 36$ & 19.91 & $32 \cdot 37$ & 3.33 & 29.00 & $9 \cdot 00$ & $40 \cdot 39$ \\
\hline Black soldier fly, larva (Hermetiaillucens) & $46 \cdot 7$ & 23.25 & $15 \cdot 60$ & $17 \cdot 30$ & $28 \cdot 75$ & $28 \cdot 57$ & 6.94 & $16 \cdot 00$ & 0.19 & $16 \cdot 54$ & $6 \cdot 26$ & 26.01 \\
\hline NRC MR Canine for growth & $18 \cdot 0$ & $6 \cdot 3$ & $3 \cdot 1$ & $5 \cdot 2$ & $10 \cdot 3$ & $7 \cdot 0$ & $2 \cdot 8$ & $5 \cdot 2$ & NR $\ddagger$ & 6.5 & $1 \cdot 8$ & $5 \cdot 4$ \\
\hline NRC MR Feline for growth & $18 \cdot 0$ & $7 \cdot 7$ & 2.6 & $4 \cdot 3$ & $10 \cdot 2$ & $6 \cdot 8$ & 3.5 & $4 \cdot 0$ & 0.32 & $5 \cdot 2$ & 1.3 & $5 \cdot 1$ \\
\hline
\end{tabular}

CP, Crude protein; NRC MR, National Research Council Minimal Requirement; NR, not required; NA, not adequate sample for analysis.

*Sample for each amino acid determination analysed in duplicate and reported as a mean value, with the exception of Trp in which only one sample was analysed due to sample size.

†Crude protein expressed on a \% (w/w) DM basis.

$\ddagger$ Taurine is not considered an essential amino acid in the dog.

specifically analysed in this preliminary study, prune juice concentrate obtained from local sources in Davis, CA has also been reported to contain taurine $(0 \cdot 02-0 \cdot 16 \mathrm{~g} / \mathrm{kg}$ as is), although source and method of processing yielded different results $^{(28)}$. It has been notoriously difficult to identify plants that contain measurable amounts of taurine ${ }^{(5,9,29)}$, and often the amino acid is overlooked or underreported in analysis of plant matter.

Nutritional quality of plants and macroalgae have also been shown to vary with season, geographic location (soil nutrients), and environmental stress (drought, salinity, light exposure $)^{(30-33)}$. In the case of the red seaweed, Palmaria palmata, which is native to Atlantic regions, there is variation in amino acid content from year to year and season to season, with the highest protein content found in specimens collected in the winter-spring period ${ }^{(34)}$. It is possible that amino acids in the substrates analysed in our lab also vary within the described parameters, thus explaining any differences in values obtained.

Using hydrolysis to analyse low concentrations of taurine is not without error. In his review of the physiological actions of taurine, Huxtable explains that certain molecules can coelute, leading to an exaggerated peak or false identification of taurine ${ }^{(5)}$. Another potential source contributing to error could be marine organisms not rinsed from samples upon initial processing.

Preliminary results suggest that insects and some marine algal species may be practical alternatives to more traditional protein and supplemental taurine sources in pet foods. Safety, bioavailability, palatability and source variability of alternative items as feed ingredients should be investigated prior to incorporation into canine and feline diets.

\section{Supplementary material}

The following text to be added when online supplementary material given: The supplementary material for this article can be found at http://www.journals.cambridge.org/jns

\section{Acknowledgements}

The authors thank Karl Menard and associates at the Bodega Marine Laboratory, Bodega Bay, CA for collecting macroalgae and Xien Wang, Department of Land, Air and Water 
Resources, University of California, Davis, for assistance in drying specimens. S. M. and A. J. F. developed the study concept and design. S. M. and Z. Y. conducted the study and developed the laboratory methods, processed samples and completed the amino acid analysis, S. M., A. J. F. and P. R. B. analysed the data and interpreted results, S. M. and A. J. F. drafted the manuscript, A. J. F. and P. R. B. made critical revisions of the manuscript. All authors read and approved the final manuscript. This work was supported by a gift from The Nutro Company. The work was conducted in the Department of Molecular Biosciences, School of Veterinary Medicine, University of California, Davis. P. R. B. is an employee of The Nutro Company, support for S. M.'s graduate position was provided by an educational grant from The Nutro Company. A. J. F. serves on an advisory board for The Nutro Company.

This paper was published as part of the WALTHAM International Nutritional Sciences Symposium Proceedings 2013, publication of which was supported by an unrestricted educational grant from Mars Incorporated. The papers included in these proceedings were invited by the Guest Editor and have undergone the standard journal formal review process. They may be cited.

\section{References}

1. American Veterinary Medical Association (2012) U.S. Pet ownership statistics. In U.S. Pet Ownership \& Demographics Sourcebook, 2012 ed. Schaumburg, IL: American Veterinary Medical Association. https://www.avma.org/KB/Resources/Statistics/Pages/Marketresearchstatistics-US-pet-ownership.aspx\#companion (accessed October 2013).

2. American Veterinary Medical Association (2012) U.S. Pet ownership statistics. In U.S. Pet Ownership \& Demographics Sourcebook, 2012 ed. Schaumburg, IL: American Veterinary Medical Association. https://www.avma.org/KB/Resources/Statistics/Pages/Marketresearchstatistics-US-Pet-Ownership-Demographics-Sourcebook. aspx (accessed October 2013).

3. Swanson KS, Carter RA, Yount TP, et al. (2013) Nutritional sustainability of pet food. Adv Nutr 4, 141-150.

4. National Research Council ad hoc Committee on Dog and Cat Nutrition (2006) Nutrient requirements and dietary nutrient concentration. In Nutrient Requirements of Dogs and Cats, pp. 354-370. Washington, DC: National Academy Press.

5. Huxtable RJ (1992) Physiological actions of taurine. Physiol Rev 72, 101-163.

6. Sanderson SL (2006) Taurine and carnitine in canine cardiomyopathy. Vet Clin North Am Small Anim Pract 36, 1325-1343.

7. Kataoka H \& Ohnishi N (1986) Occurrence of taurine in plants. Agric Biol Chem 50, 1887-1888.

8. Stintzing F, Schieber A \& Carle R (1999) Amino acid composition and betaxanthin formation in fruits from Opuntia ficus-indica. Plant Med 65, 632-635.

9. Spitze AR, Wong DL, Rogers QR, et al. (2003) Taurine concentrations in animal feed ingredients; cooking influences taurine content. J Anim Physiol Anim Nutr 87, 251-262.

10. Tesoriere L, Fazzari M, Allegra M, et al. (2005) Biothiols, taurine, and lipid-soluble antioxidants in the edible pulp of Sicilian cactus pear (Opuntia ficus-indica) fruits and changes of bioactive juice components upon industrial processing. I Agric Food Chem 53, 7851-7855.

11. Hayes KC, Carey RE \& Schmidt SY (1975) Retinal degeneration associated with taurine deficiency in the cat. Science 188, 949-951.

12. Pion PD, Kittleson MD, Rogers QR, et al. (1987) Myocardial failure in cats associated with low plasma taurine: a reversible cardiomyopathy. Science 237, 764-768.
13. Morris JG, Rogers QR \& Pacioretty LM (1990) Taurine: an essential nutrient for cats. J Sm Anim Pract 31, 502-509.

14. Association of American Feed Control Officials (AAFCO) (2013) Model regulations for pet and specialty pet food under the model bill. In 2013 Official Publication, pp. 135-150 [L Higgins, section editor]. Champaign, IL: Association of American Feed Control Officials, Inc.

15. The European Pet Food Industry Federation (FEDIAF) (2008) Nutritional guidelines for complete and complementary pet food for cats and dogs. http://www.fediaf.org/self-regulation/ (accessed October 2013).

16. Kittleson MD, Keene B, Pion PD, et al. (1997) Results of the Multicenter Spaniel Trial (MUST): taurine- and carnitine-responsive dilated cardiomyopathy in American cocker spaniels with decreased plasma taurine concentration. J Vet Int Med 11, 204-211.

17. Fascetti AJ, Reed JR, Rogers QR, et al. (2003) Taurine deficiency in dogs with dilated cardiomyopathy: 12 cases (1997-2001). J Am Vet Med Assoc 223, 1137-1141.

18. Backus RC, Cohen G, Pion PD, et al. (2003) Taurine deficiency in Newfoundlands fed commercially available complete and balanced diets. J Am Vet Med Assoc 223, 1130-1136.

19. Laflamme DL, Abood SK, Fascetti AJ, et al. (2008) Pet feeding practices of $\operatorname{dog}$ and cat owners in the United States and Australia. J Am Vet Med Assoc 232, 687-694.

20. Michel KE, Willoughby KN, Abood SK, et al. (2008) Attitudes of pet owners toward pet foods and feeding management of cats and dogs. J Am Vet Med Assoc 233, 1698-1703.

21. AOAC Official Method 994.12 (2005) Amino acids in feeds. In Official Methods of Analysis of AOAC International, 18th ed., Revision 1, pp. 9-19. Gaithersburg, MD: AOAC International.

22. AOAC Official Method 988.15 (2005) Tryptophan in foods and food and feed ingredients. In Official Methods of Analysis of $A O A C$ International, 18th ed., Revision 1, pp. 88-89. Gaithersburg, MD: AOAC International.

23. AOAC Official Method 990.03 (2005) Protein (Crude) in animal feed, combustion method. In Official Methods of Analysis of $A O A C$ International, 18th ed., Revision 1, pp. 30-31. Arlington, VA: AOAC International.

24. AOAC Official Method 972.43 (2006) Microchemical determination of carbon, hydrogen, and nitrogen, automated method. In Official Methods of Analysis of $A O A C$ International, 18th ed., Revision 1, pp. 5-6. Gaithersburg, MD: AOAC International.

25. Finke MD (2002) Complete nutrient composition of commercially raised invertebrates used as food for insectivores. Zoo Biol 21, 269-285.

26. Fleurence J (1999) Seaweed proteins: biochemical, nutritional aspects and potential uses. Trends Food Sci Technol 10, 25-28.

27. Fernandez-Lopez JA, Almela L, Obon JM, et al. (2010) Determination of antioxidant constituents incactus pear fruits. Plant Foods Hum Nutr 65, 253-259.

28. van Gorsel H, Li C, Kerbel EL, et al. (1992) Compositional characterization of prune juice. J Agric Food Chem 40, 784-789.

29. Pasantes-Morales H, Quesada O, Alcocer L, et al. (1989) Taurine content in foods. Nutr Rep Int 40, 793-801.

30. Robbins CT (1993) Food composition. In Wildlife Feeding and Nutrition, 2nd ed., pp. 247-265 [TJ Cunha, editor]. San Diego, CA: Academic Press, Inc.

31. Gzik A (1996) Accumulation of proline and pattern of $\alpha$-amino acids in sugar beet plants in response to osmotic, water and salt stress. Environ Exp Bot 36, 29-38.

32. Schmidt DA, Kerley MS, Porter JH, et al. (2005) Structural and nonstructural carbohydrate, fat, and protein composition of commercially available, whole produce. Zoo Biol 24, 359-373.

33. Baer CK, Ullrey DE, Schlegel ML, et al. (2010) Contemporary topics in wild mammal nutrition. In Wild Mammals in Captivity: Principals and Techniques for Zoo Management. pp. 85-103 [DG Kleiman, KV Thompson and CK Baer, editors]. Chicago, IL: The University of Chicago Press.

34. Galland-Irmouli AV, Fleurence J, Lamghari R, et al. (1999) Nutritional value of proteins from edibleseaweed Palmaria palmata (Dulse). J Nutr Biochem 10, 353-359. 